\title{
Atmospheric Dispersion Modeling for the Worst-Case Detonation Accident at the Proposed Advanced Hydrotest Facility
}

\author{
Brent M. Bowen \\ Brenda M. Pobanz
}

October 22, 1996

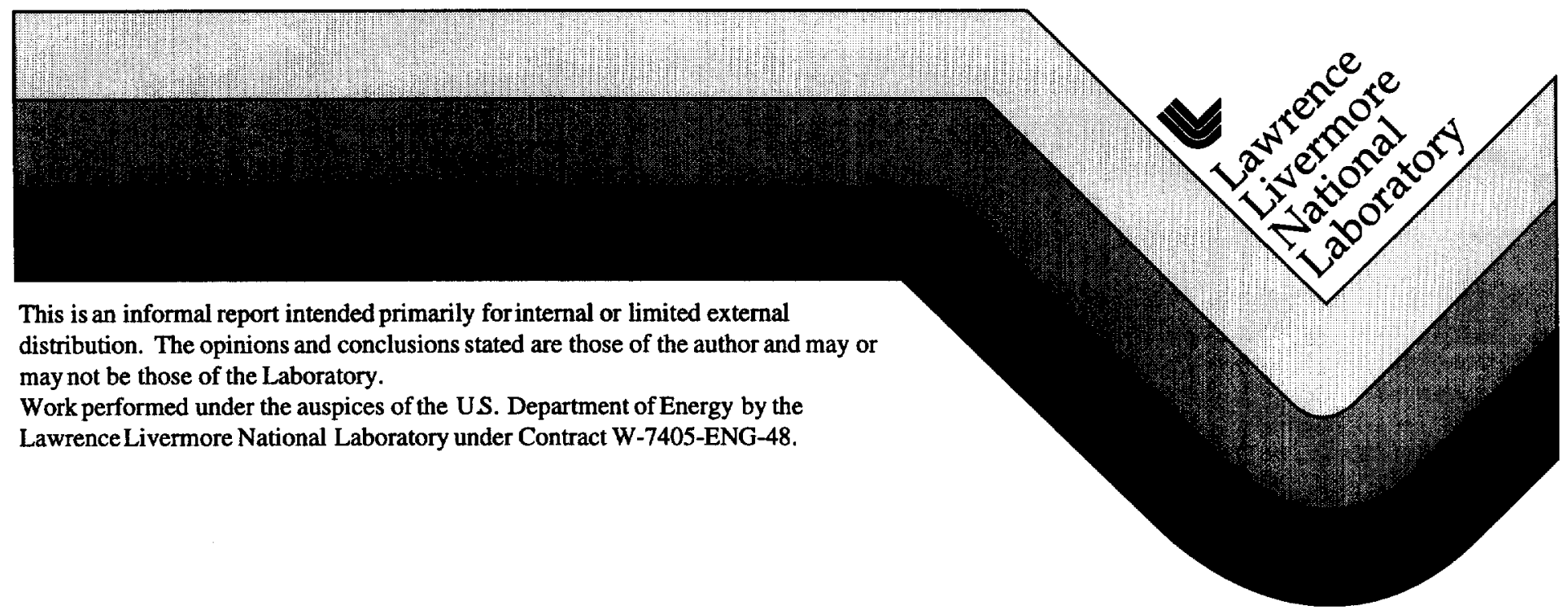




\section{DISCLAIMER}

This document was prepared as an account of work sponsored by an agency of the United States Government. Neither the United States Government nor the University of California nor any of their employees, makes any warranty, express or implied, or assumes any legal liability or responsibility for the accuracy, completeness, or usefulness of any information, apparatus, product, or process disclosed, or represents that its use would not infringe privately owned rights. Reference herein to any specific commercial product, process, or service by trade name, trademark, manufacturer, or otherwise, does not necessarily constitute or imply its endorsement, recommendation, or favoring by the United States Government or the University of California. The views and opinions of authors expressed herein do not necessarily state or reflect those of the United States Government or the University of California, and shall not be used for advertising or product endorsement purposes.

This report has been reproduced directly from the best available copy.

Available to DOE and DOE contractors from the Office of Scientific and Technical Information

P.O. Box 62, Oak Ridge, TN 37831

Prices available from (615) 576-8401, FTS 626-8401

Available to the public from the

National Technical Information Service

U.S. Department of Commerce

5285 Port Royal Rd.,

Springfield, VA 22161 


\title{
Atmospheric Dispersion Modeling for the Worst-Case Detonation Accident at the Proposed Advanced Hydrotest Facility
}

\author{
by \\ Brent M. Bowen \\ and \\ Brenda M. Pobanz
}

Atmospheric Release Advisory Capability Lawrence Livermore National Laboratory Livermore, California USA

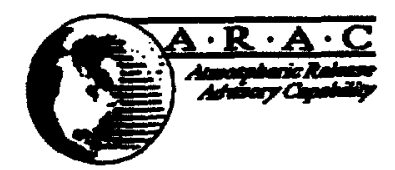

Prepared for

Defense Sciences/Nuclear Design Program Lawrence Livermore National Laboratory

Livermore, California USA 
Table of Contents

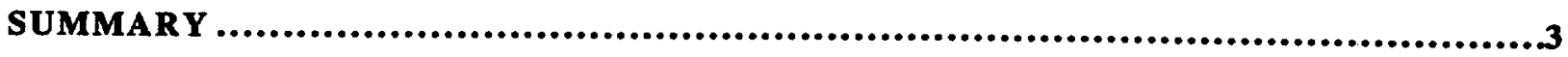

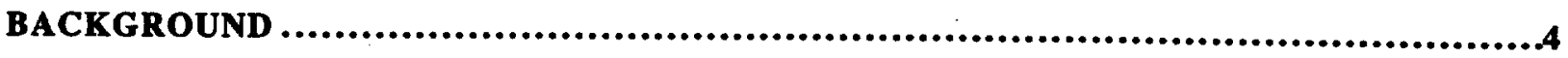

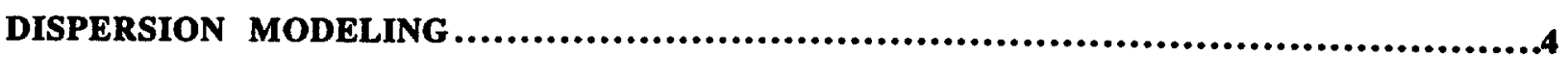

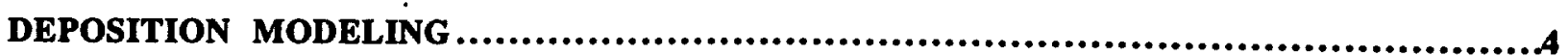

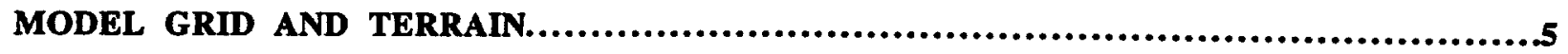

METEOROLOGY..........................................................................6

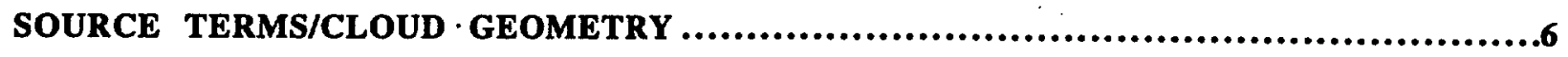

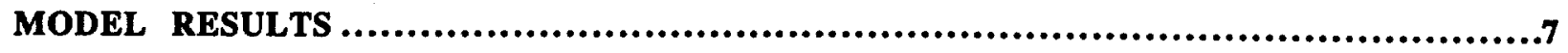

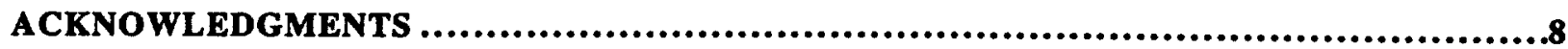

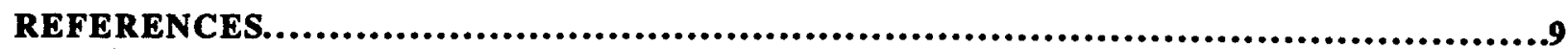

APPENDIX A.1 WORST CASE 50-YR COMMITTED EFFECTIVE WHOLE BODY DOSE PLOT (PER KG OF PLUTONIUM) FOR NEAREST

ONSITE LOCATION. ......................................................................10

APPENDIX A.2 WORST CASE 50-YR COMMITTED EFFECTIVE WHOLE BODY DOSE PLOT (PER KG OF PLUTONIUM) FOR NEAREST

OFFSITE LOCATION.

APPENDIX B.1 WORST CASE DEPOSITION PLOT (PER KG OF

PLUTONIUM) FOR NEAREST ONSITE LOCATION.

APPENDIX B.2 WORST CASE DEPOSITION PLOT (PER KG OF

PLUTONIUM) FOR NEAREST OFFSITE LOCATION.

APPENDIX C.1 WORST CASE ATMOSPHERE BERYLLIUM CONCENTRATION PLOT (PER KG OF BE) FOR NEAREST ONSITE

LOCATION..

APPENDIX C.2 WORST CASE ATMOSPHERE BERYLLIUM CONCENTRATION PLOT (PER KG OF BE) FOR NEAREST OFFSITE

LOCATION..

APPENDIX D.1 WORST CASE ATMOSPHERIC HF CONCENTRATION

PLOT FOR NEAREST ONSITE LOCATION. 16

APPENDIX D.2 WORST CASE ATMOSPHERIC HF CONCENTRATION

PLOT FOR NEAREST OFFSITE LOCATION.

APPENDIX E. PERMISSIBLE LIMITS. 


\title{
Atmospheric Dispersion Modeling for the Worst-Case Detonation Accident at the Proposed Advanced Hydrotest Facility
}

\author{
Brent M. Bowen \\ and \\ Brenda M. Pobanz \\ Atmospheric Release Advisory Capability \\ Lawrence Livermore National Laboratory \\ Livermore, California USA
}

\section{Summary}

The Atmospheric Release Advisory Capability (ARAC) was requested to estimate credible worst-case dose, air concentration, and deposition of airborne hazardous materials that would result from a worst-case detonation accident at the proposed Advanced Hydrotest Facility (AHF) at the Nevada Test Site (NTS). Consequences were estimated at the closest onsite facility, the Device Assembly Facility (DAF), and offsite location (intersection of Mercury Highway and U.S. 95). The materials considered in this analysis were weapon-grade plutonium, beryllium, and hydrogen fluoride which is a combustion product whose concentration is dependent upon the quantity of high explosives. The analysis compares the calculated results with action guidelines published by the Department of Defense in DoD 5100.52-M (Nuclear Weapon Accident Response Procedures).

Results indicate that based on a one $\mathrm{kg}$ release of plutonium, the whole body radiation dose could be as high as 3 Rem at the DAF. This level approaches the 5 Rem level for which the Department of Defense requires respiratory protection, recommends sheltering and the consideration of evacuation. Deposition levels at the DAF could approach $6 \mathrm{uCi} / \mathrm{m}^{2}$ for which the Department of Defense recommends access on a need-only basis and suggests that a possible controlled evacuation might be required.

For a one $\mathrm{kg}$ release of plutonium, the dose at the nearest off-site location could reach 0.5 Rem. At this level, the Department of Defense suggests that sheltering be considered.

For a one $\mathrm{kg}$ release of beryllium, the peak 5-minute concentration at the DAF could be as high as $20 \%$ of $6 \times 10^{-3} \mathrm{mg} / \mathrm{m}^{3}$ which is the applicable Emergency Response Planning Guideline (ERPG-1). At the nearest offsite location, the beryllium concentrations from a one $\mathrm{kg}$ release would be two orders of magnitude less than the same guideline.

For the detonation of $100 \mathrm{~kg}$ of the explosive $\mathrm{LX}-17$, the concentration of hydrogen fluoride at both the DAF and the nearest offsite location would be four orders of magnitude less than the lowest applicable Emergency Response Planning Guideline (ERGP-1).

The calculations and analysis reported here indicate that emergency response planning for such an accident at the present proposed location of the AHF should include provisions for the protection of personnel located at the DAF and their possible evacuation. In addition, emergency response planning should consider what actions might be desirable for the protection 
of the public at off-site locations where the calculations indicate that the whole body radiation dose might approach the 0.5 Rem value for which the Department of Defense recommends that sheltering be considered.

\section{Background}

B-Division of the Defense Sciences/Nuclear Design Program asked ARAC to estimate worstcase dose, air concentrations, and deposition of airborne hazardous materials that would result from an improbable worst-case detonation accident at the proposed AHF. The AHF will be used to study the hydrodynamics of a variety of explosives and assemblies of explosives with other materials.

This report estimates the consequences that would occur in the unlikely event that a device detonates when transported from the DAF to the containment vessel at the DAF. This report is intended to assist B-Division in developing a Preliminary Safety Analysis Report (PSAR).

\section{Dispersion Modeling}

The ARAC operational models, CG-MATHEW (Conjugate-Gradient Mass-Adjusted THrEedimensional Wind) and ADPIC (Atmospheric Dispersion by Particle-in-Cell), were used to compute the doses, air concentrations, and deposition in this assessment. Sullivan et al. (1993) summarizes the ARAC program and the accuracy of the CG-MATHEW/ADPIC operation models. The newest version of ADPIC, the Random Displacement Method (Nasstrom, 1995), was adopted by ARAC in 1995 and was used in this assessment. The cloud rise and geometry were calculated from the number of pounds of high explosives (HE) based on Roller Coaster experiments (See Church, 1969 and Stewart, 1969).

\section{Deposition Modeling}

Dry deposition of airborne material onto the ground is affected by several processes:

(1) turbulent diffusion of material toward the surface,

(2) gravitational settling of material toward the surface,

(3) flux of material from the near-surface layer to the ground itself.

ADPIC models each of these processes separately. Time- and space-varying atmospheric turbulent diffusion is calculated using the Random Displacement Method. Gravitational settling is modeled by the particle size dependent Stokes law settling velocity (for example, the Stokes settling velocities are 0.0026 and $0.029 \mathrm{~cm} / \mathrm{sec}$ for particles with diameters of 0.3 and $1.0 \mu$, respectively), for a Reynolds number less than or equal to one. The McDonald (1960) method is used for a Reynolds number greater than one. The particle size distribution used for plutonium and beryllium contained in the detonation cloud is described in Table 1. 


\begin{tabular}{lc}
\hline $\begin{array}{l}\text { Log-normal } \\
\text { Size Distribution }\end{array}$ & $\begin{array}{c}\text { Particle } \\
\text { Diameter }\end{array}$ \\
\hline Pattern & $(\mu \mathrm{m})$ \\
\hline Maximum & 200 \\
Median & 40 \\
Minimum & 0.2 \\
Standard Geometric Deviation & 5.71 \\
\hline
\end{tabular}

Table 1. Log-normal particulate size distribution.

The dry deposition flux of material to the ground is parameterized using the deposition velocity, which is typically greater than or equal to the gravitational settling velocity. Data on deposition velocities are limited. Specific deposition velocities can vary by two orders of magnitude because of their dependence upon many factors (McMahon and Denison, 1979). Since deposition velocity typically ranges from 0.1 to $10 \mathrm{~cm} / \mathrm{sec}$, a value of $1 \mathrm{~cm} / \mathrm{sec}$ was used in this study.

\section{Model Grid and Terrain}

The adjustable calculational grid used in the CG-MATHEW/ADPIC models is fixed for each run. A "nested" grid is used in sampling airborne and ground-deposited ADPIC "marker" particles for air concentration, dose, and deposition calculations. The highest resolution occurs adjacent to the source with dimensions $1 / 16$ of the calculational grid size. Two calculational grids were used in this study: a large one used to calculate the nearest offsite consequences and a smaller one used to study onsite consequences. Table 2 lists the dimensions of the model grids used in this study. Terrain cells with 500 and $100 \mathrm{~m}$ resolution were input to the large and small grids, respectively.

\begin{tabular}{l|c|c|c}
\hline & North-South & East-West & Vertical \\
\hline \hline Number of cells & 40 & 40 & 14 \\
\hline Individual cell size & $1.25(0.5) \mathrm{km}$ & $1.25(0.5 \mathrm{~km})$ & $75(50) \mathrm{m}$ \\
\hline Grid domain & $50(20) \mathrm{km}$ & $50(20) \mathrm{km}$ & $1050(700) \mathrm{m}$ \\
\hline
\end{tabular}

Table 2. Model grid sizes. Values for individual cell size and grid domain represent large and (small) grids, respectively.

The proposed AHF site, latitude $36^{\circ} 52^{\prime} 05^{\prime \prime} \mathrm{N}$ and longitude $116^{\circ} 03^{\prime} 47^{\prime \prime} \mathrm{W}$, was placed on the north-central portion of the larger grid to optimize consequence analysis at the intersection of US 95 and Mercury Highway, located about 20 miles $(32 \mathrm{~km})$ to the SSE. The AHF was placed at the center of the smaller grid and includes the DAF, located 2.3 miles $(3.7 \mathrm{~km}) \mathrm{NNE}$ of the AHF. The elevations in meters are 1124, 1126, and 1131 ASL at the AHF, DAF, and U.S. 95/Mercury Hwy sites, respectively. While the elevation is nearly identical at all three sites, the models accounted for modest sloping of terrain during downwind transport. Also, the models 
accounted for channeling of winds caused by surrounding terrain, especially during the most stable (F) atmospheric conditions.

\section{Meteorology}

Meteorological inputs were estimated and input to produce credible worst-case downwind consequences. The primary inputs are profiles of wind direction and speed, atmospheric stability, and mixing height. The determination of realistic worst-case meteorological conditions for an elevated source is complicated, since the most stable $(F)$ conditions that cause the highest downwind cloud concentrations may prevent downward mixing to the ground. Therefore, separate runs were made for all Pasquill-Gifford $(P-G)$ stability categories (i.e., $A$ through $F$ ) for each of the two grids. However, $F$ stability was not used to calculate worst-case consequences for the offsite consequences, since the combination of $F$ stability, no low-level direction wind shear, and very light winds persisting over four to six hours is unrealistic.

Constant wind-direction profiles from the NNW and SSW were used to determine the nearest offsite and onsite consequences, respectively. These directions transport the centerline of the detonation (i.e., highest dose, concentrations, and deposition) to the U.S. 95/Mercury Highway and DAF locations. Wind speed profiles were calculated for each P-G category using a method suggested by Hanna et al. (1982). Wind speed profiles and mixing heights according to stability category are shown in Table 3.

\begin{tabular}{cccccc}
\hline & \multicolumn{5}{c}{ Pasquill-Gifford (P-G) Stability Category } \\
\cline { 3 - 6 } Height (m AGL) & A/B & C & D & E & F \\
\hline 1000 & & & & & \\
500 & 2.0 & 4.0 & 5.0 & 4.0 & 3.0 \\
300 & 2.0 & 4.0 & 5.0 & 4.0 & 3.0 \\
10 & 1.9 & 4.0 & 5.0 & 4.0 & 3.0 \\
$\begin{array}{c}\text { Mixing height } \\
\text { (m AGL) }\end{array}$ & 1.5 & 3.0 & 4.0 & 2.0 & 1.5 \\
\hline
\end{tabular}

Table 3. Wind speed $(\mathrm{m} / \mathrm{s})$ profiles and mixing height as a function of stability category.

\section{Source Terms/Cloud Geometry}

A listing of materials likely to be tested at the AHF can be found in the Preliminary Safety Analysis Report (PSAR) for Site 300 Contained Firing Facility (Lyle, 1993). Beryllium and the explosive LX-17 were chosen from a materials listing in this report because they represent the most potentially hazardous, aerosolized, and non-radioactive materials in the list. Plutonium was added for analysis.because it is radioactive and experiments have been proposed for the AHF that would include it. This study examined consequences from releases of weapon-grade plutonium, beryllium, and Hydrogen Fluoride (HF). The source terms for these three materials are listed in Table 4. Note that the amount of HF (a combustion product) is dependent upon the amount of high explosives (HE), while one $\mathrm{kg}$ was used for plutonium and for beryllium. The release was assumed to occur over a two minute period from the detonation cloud. 


\begin{tabular}{lcccc}
\hline & \multicolumn{3}{c}{ HE amount } \\
\cline { 2 - 4 } \multicolumn{1}{c}{ Material } & $10 \mathrm{~g}$ & $50 \mathrm{lb}$. & $100 \mathrm{lb}$. \\
\hline Plutonium (kg) & 1 & 1 & 1 \\
Beryllium (kg) & 1 & 1 & 1 \\
HF (g) & 0.4 & 909 & 1818 \\
\hline
\end{tabular}

Table 4. Source terms used in modeling.

The detonation cloud was described by a top (fireball) and bottom (stem) cloud. The heights of the top, middle, and bottom of the two cloud portions as well as the geometry depend upon the amount of HE. While LX-17, the HE proposed for use at the AHF, is 1.0 to 1.3 times as energetic as TNT, equations that estimate cloud geometry based on pounds of TNT were used (i.e., the additional energy of LX-17 was neglected). This results in slightly lower and more dense clouds, and hence slightly conservative downwind consequences. Model runs were made for detonation clouds resulting from $10 \mathrm{~g}, 50 \mathrm{lb}$., and $100 \mathrm{lb}$. of $\mathrm{HE}$. All detonations were assumed to occur at the surface.

Finally, an activity rate of $8.02 \times 10^{-2} \mathrm{Ci} / \mathrm{g}$ was used for the weapon-grade plutonium, assuming an age of one year. This results in a whole-body dose factor of $3.39 \times 10^{8} \mathrm{Rem} / \mathrm{Ci}$ assuming an adult breathing rate of $3.3 \times 10^{-4} \mathrm{~m}^{3} / \mathrm{s}$. Only $20 \%$ of the material was assumed to be respirable. The resultant 50-year committed effective dose equivalent (CEDE) calculated in this study assumes that an adult stood on the ground and breathed normally during the entire cloud passage and that the particles are retained in the body for 50 years thereafter.

\section{Model Results}

Worst-case meteorology and downwind consequences are shown in Table 5 for the closest onsite and offsite locations. The worst-case contour plots are also shown for dose, deposition, beryllium concentrations, and HF concentrations in Appendixes A to D, respectively. Permissible limits for dose and deposition based on the Nuclear Weapon Accident Response Procedures (NARP, 1990) and for beryllium and HF based on Emergency Response Planning Guidelines (ERPGs) are shown in Appendix E.

The dose, deposition, and beryllium atmospheric concentrations are greatest at the DAF for the most stable $(F)$ atmosphere and the 50-pound $\mathrm{HE}$ scenario. All three values are much less for the small (10g) HE case since much of the material in the small and shallow cloud settles to the ground during transport to the DAF. Conversely, a larger and taller cloud resulting from 100 pounds of $\mathrm{HE}$ lofts more material higher above the ground before it settles over the ground at DAF. The somewhat less conservative $E$ stability was determined to cause the most impact at the intersection of U.S. 95 and Mercury Highway for all dose, deposition, and atmospheric concentrations, since the combination of steady, light winds, constant wind direction with height, and $F$ stability persisting over 4 to 6 hours or so of transport (i.e, 20 miles) is unrealistic and overly conservative. The $100 \mathrm{lb} \mathrm{HE}$ cloud scenario produced the highest HF concentrations averaged over 5 minutes at both sites, since the amount of HF produced by the combustion is proportional to the amount of HE. Note that 5-minute HF concentrations increased by about a factor of 20 at four $\mathrm{km}$ downwind of DAF, where terrain increases by $200 \mathrm{~m}$ or so. 


\begin{tabular}{lcc|cc}
\hline & $\begin{array}{c}\text { DAF } \\
\text { F Stability } \\
\text { Meteorology: }\end{array}$ & $\begin{array}{c}\text { \#lb HE } \\
@ 1.5 \mathrm{~m} / \mathrm{s}\end{array}$ & $\begin{array}{c}\text { Hwys. } \\
\frac{95 / \text { Mercury }}{\text { E stability }}\end{array}$ & \#lb HE \\
dose (Rem) & 3.0 & 50 & $5.3 \times 10^{-1}$ & 100 \\
deposition $\left(\mu \mathrm{Ci} / \mathrm{m}^{2}\right)$ & 4.9 & 50 & $3.0 \times 10^{-1}$ & 100 \\
5-min Be (mg $\left./ \mathrm{m}^{3}\right)$ & $1.3 \times 10^{-3}$ & 50 & $7.2 \times 10^{-5}$ & 100 \\
5-min HF (ppm) & $6.1 \times 10^{-4}$ & 100 & $3.4 \times 10^{-4}$ & 100 \\
\hline
\end{tabular}

Table 5. Worst-case meteorology and model results at nearest onsite (DAF) and offsite (Hwys. 95/Mercury) locations. Source: $1 \mathrm{~kg} \mathrm{Pu,} 1 \mathrm{~kg} \mathrm{Be,} \mathrm{LX-17} \mathrm{as} \mathrm{tabulated.}$

The impact of a worst-case detonation on downwind dose and deposition, and beryllium concentrations is directly dependent upon the quantities of these materials present. In Table 5, it is assumed that one $\mathrm{kg}$ of plutonium and one $\mathrm{kg}$ of beryllium have been aerosolized. Dose levels at the DAF would approach the value of 5 Rem which would require sheltering and suggest respiratory protection. Deposition levels at the DAF would approach the value of $6 \mathrm{uCi} / \mathrm{m}^{2}$ which suggests access on a need-only basis and possible controlled evacuation.

At the nearest offsite location (Mercury Hwy. and Hwy. 95), the calculated dose is 0.53 Rem. The Department of Defense recommends the consideration of sheltering at a level of 0.5 Rem. The deposition level there is $5 \%$ of the DoD emergency response triggering level of $6 \mathrm{uCi} / \mathrm{m}^{+2}$.

Maximum atmospheric beryllium concentrations are less than $22 \%$ of the lowest threshold (ERPG-1) at the DAF and $1.2 \%$ of the same threshold at the nearest offsite location.

At both the DAF and the nearest offsite location the concentration of HF is approximately four orders of magnitude less than the lowest threshold (ERPG-1).

Worse-case downwind doses and deposition resulting from plutonium and atmospheric concentrations of beryllim at both the closest onsite and offsite locations can be calculated by multiplying the values in Table 5 by the number of kilograms of the materials contained in a test assembly. This would be a worst-case calculation. Of the total quantity of these materials in an assembly, only a fraction may become aerosolized. In general, materials contained inside cavities of explosives become finely divided, heated and aerosolized, while those materials located outside explosives become fragmented and can be found on the ground and collected after a detonation.

\section{Acknowledgments}

The authors appreciate the efforts of Jim Lyle in B-Division for reviewing this report and for suggesting revisions that helped clarify the report. Jim Ellis and Tom Sullivan of ARAC also reviewed the report and provided helpful suggestions. Thanks also go the Fernando Aluzzi, also of ARAC, for adding several features to the NTS geography. Finally, the authors thank Lourdes Placeres for preparing this report.

The work was performed under the auspices of the U.S. Department of Energy at Lawrence Livermore National Laboratory under contract number W-7405-Eng-48. 


\section{References}

Church, H.W., 1969: Cloud rise from high-explosives detonations. Sandia Laboratories, Albuquerque, Report SC-RR-68-903, Health and Safety UC-41, TID-4500.

Hanna, S.R., G.A. Briggs, and R.P. Hosker, 1982: Handbook on atmospheric diffusion. Atmospheric Turbulence and Diffusion Laboratory, National Oceanic and Atmospheric Administration, DOE/TIC-11223.

Lyle, J.W., 1993: Preliminary Safety Analysis Report (PSAR) for Site 300 Contained Firing Facility. Lawrence Livermore Report, UCRL-AR-117499.

McDonald, J.E., 1960: An aid to computation of terminal fall velocities of spheres. I. Meteor., 28, 463-465.

McMahon, T. and P. Denison, 1979: Empirical atmospheric deposition parameters-A survey. Atmos. Environ., 13(5), 571-585.

NARP (Nuclear Weapon Accident Response Procedures) Manual, September 1990, DoD 5100.52-M.

Nasstrom, J., S., 1995: Turbulence Parameterizations for the Random Displacement Method (RDM) Version of ADPIC. Lawrence Livermore Report UCRL-ID-120965.

Stewart, K., 1969: Roller Coaster: Summary Report (U), U.K. Atomic Energy Authority Report AWRE No. T6/69 (Secret).

Sullivan, T.S., J.S. Ellis, C.S. Foster, K.T. Foster, R.L. Baskett, J.S. Nasstrom, and W.W. Schalk III, 1993: Atmospheric Release Advisory Capability: Real-time modeling of airborne hazardous materials. Bull. Amer. Meteor. Soc., 74: 2343-2361. 
Appendix A.1 Worst case 50-yr committed effective whole body dose plot (per $\mathrm{kg}$ of plutonium) for nearest onsite location.

Advanced Hydrotest Facility PSAR

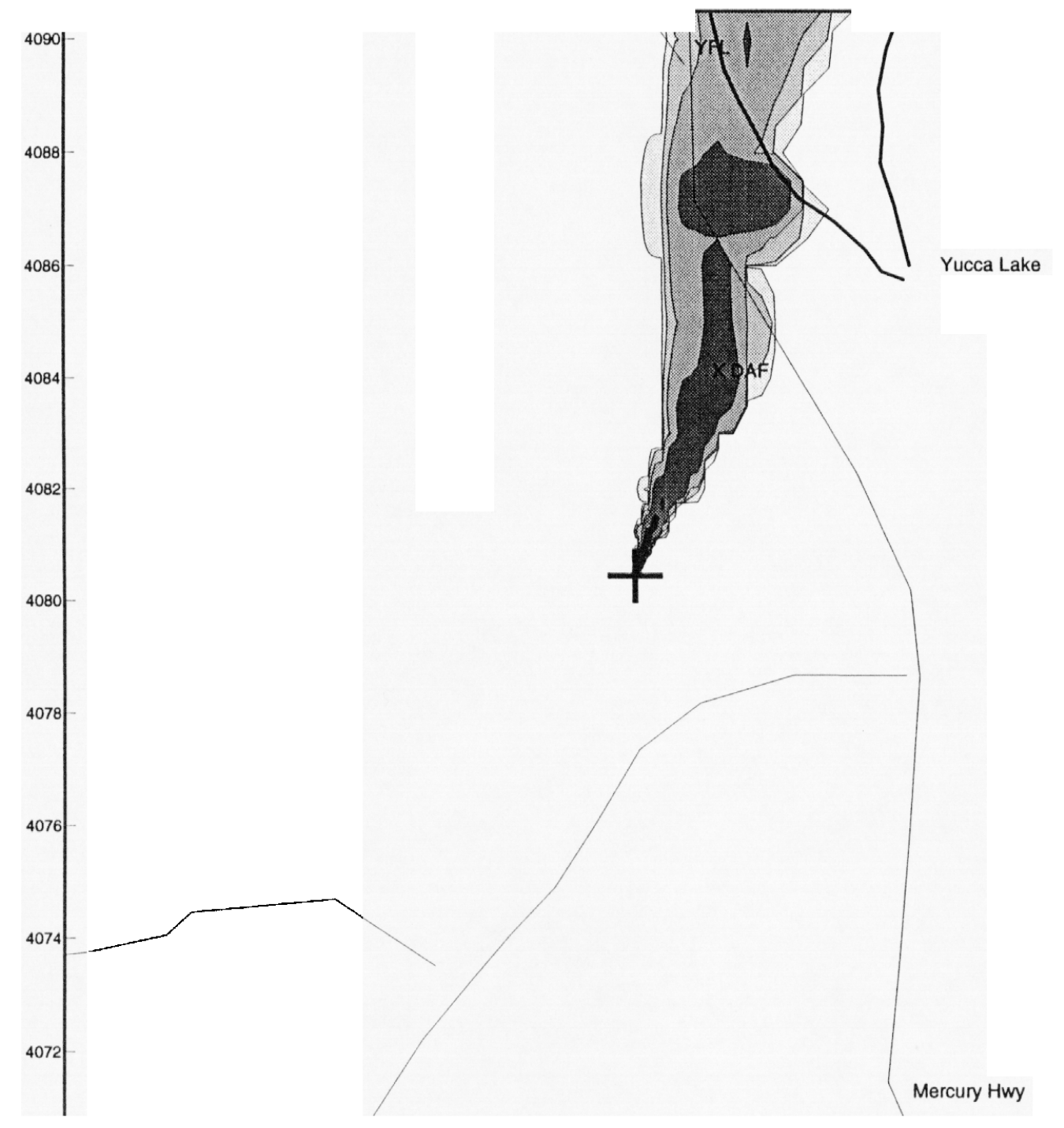

\section{9SEP96 17:59:00 UTC}

Integrated air at 1.5 meters

04MAR96 17:30:00 to 05MAR96 05:30:00 UTC

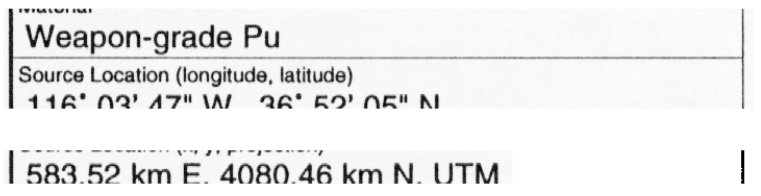

\section{INITIAL PLOT - WEAPON ACCIDENT D}

5OYRCOM EFFECTIVE WB

INHALE ADULT INTAIR

$50 \mathrm{lb}$. HE, F stability

(per kilogram of weapon-grade $\mathrm{Pu}$ )

Contours:

Level and Area Covered

$>1.00 e+01$ Rem

$0.13 \mathrm{sq} \mathrm{km}$

드 $1.00 e+00$ Rem

$5.59 \mathrm{sq} \mathrm{km}$

$\square>1.00 \mathrm{e}-01$ Rem

$13.66 \mathrm{sq} \mathrm{km}$

$\square>1.00 \mathrm{e}-02$ Rem

$16.90 \mathrm{sq} \mathrm{km}$

$\square>1.00 \mathrm{e}-03$ Rem

$19.67 \mathrm{sq} \mathrm{km}$

W5B 
A.2 Worst case 50-yr committed effective whole body dose plot (per kg of plutonium) for nearest offsite location.

\section{Advanced Hydrotest Facility PSAR}

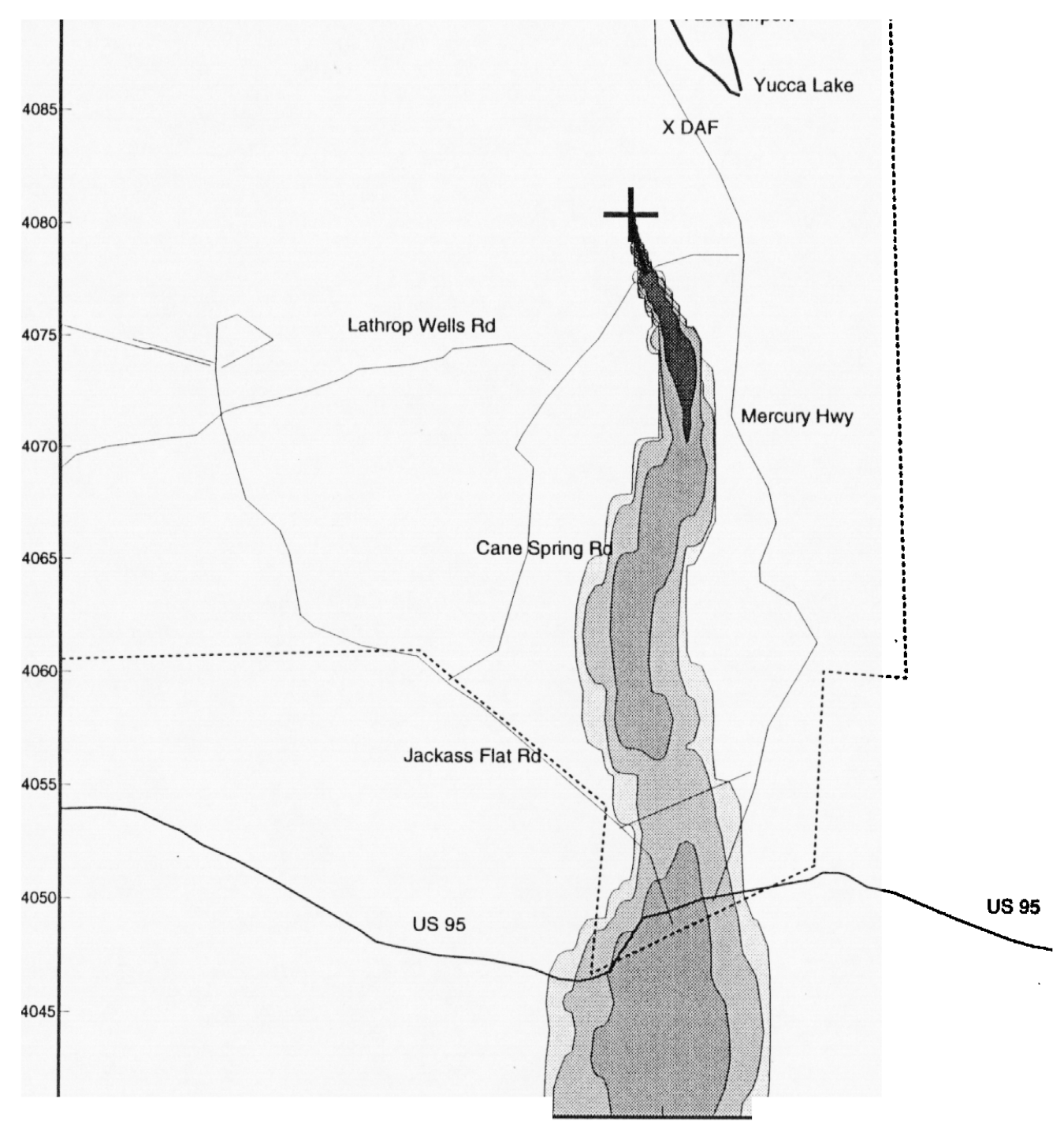

9SEP96 17:53:00 UTC

Contour Type

Integrated air at 1.5 meters

04MAR96 17:30:00 to 05MAR96 05:30:00 UTC

Weapon-grade $\mathrm{Pu}$

Source Location (longitude, latitude)

$116^{\circ} 03^{\prime} 47^{\prime \prime} \mathrm{W}, 36^{\circ} 52^{\prime} 05^{\prime \prime} \mathrm{N}$

Source Location (x,y, projection)
583.52 km E. 4080.46 km N. UTM

INITIAL PLOT - WEAPON ACCIDENT D

50YRCOM EFFECTIVE WB

INHALE ADULT INTAIR

$50 \mathrm{lb}$. HE, E stability,

(per kilogram of weapon-grade $\mathrm{Pu}$ )

Contours:

(Level and Area Covered)

- > $1.00 e+01$ Rem

$0.40 \mathrm{sq} \mathrm{km}$

III $1.00 \mathrm{e}+00$ Rem

$6.86 \mathrm{sq} \mathrm{km}$

$=1.00 \mathrm{e}-01 \mathrm{Rem}$

$89.54 \mathrm{sq} \mathrm{km}$

$\square \quad 1.00 \mathrm{e}-02$ Rem

$165.37 \mathrm{sq} \mathrm{km}$

$\square>1.00 \mathrm{e}-03$ Rem

$203.86 \mathrm{sq} \mathrm{km}$ 
Appendix B.1 Worst case deposition plot (per kg of location.

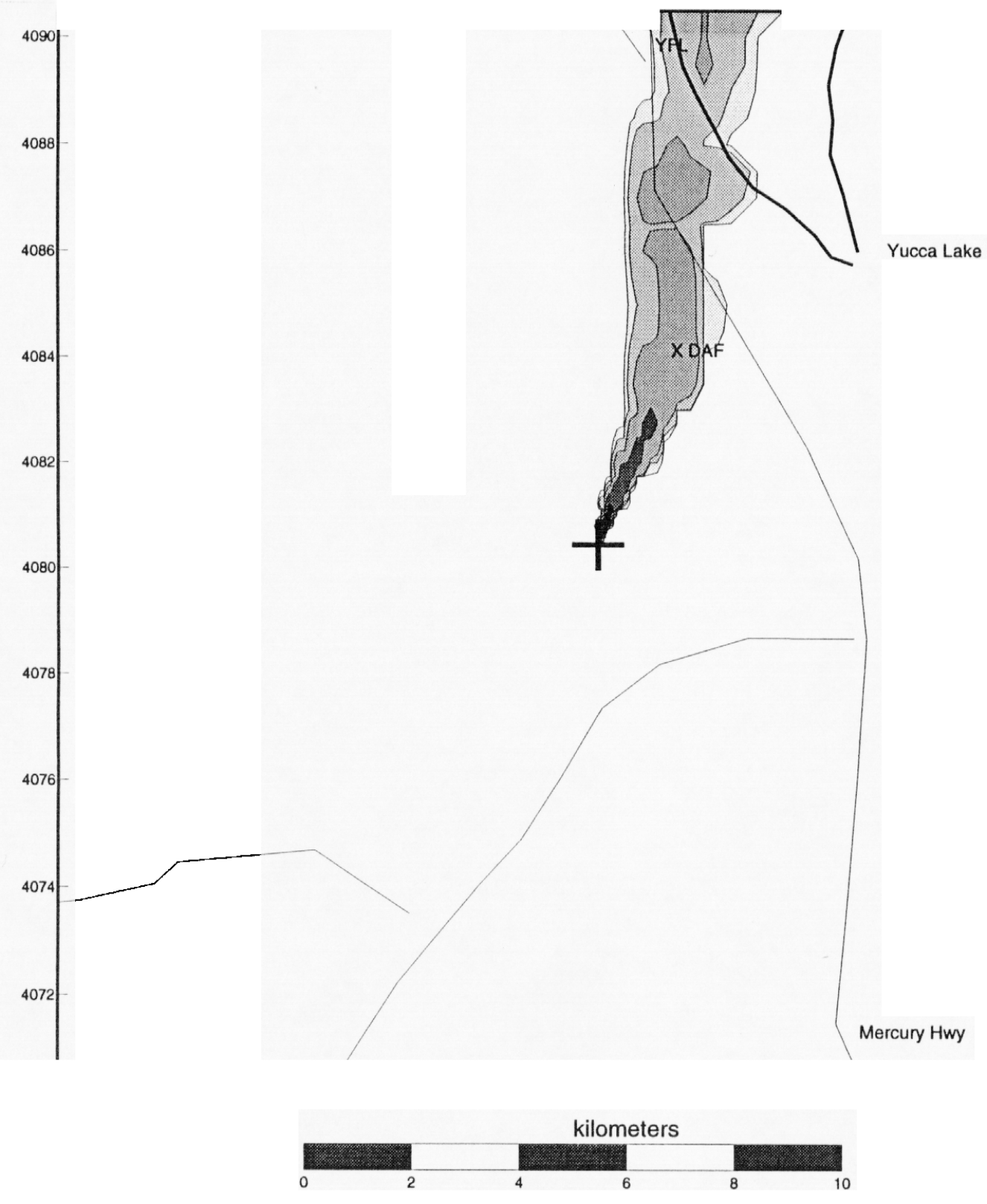

for nearest onsite

Advanced Hydrotest Facility PSAR

I 9SEP96 17:59:0ก UTC.

From Deposition at 0.0 meters

04MAR96 17:30:00 to 05MAR96 05:30:00 UTC

Material

Weapon-grade $\mathrm{Pu}$

Source Location (longitude, latitude)

Source Location (longitude, latitude)

$583.52 \mathrm{~km} \mathrm{E}, 4080.46 \mathrm{~km} \mathrm{~N}$, UTM

\section{Pomaks}

INITIAL PLOT - WEAPON ACCIDENT D

$50 \mathrm{lb}$. HE, F stability

(per kilogram of weapon-grade $\mathrm{Pu}$ )

Contours:

(Level and Area Covered)

$>1.00 \mathrm{e}+02 \mathrm{uCi} / \mathrm{m} 2$

$0.07 \mathrm{sq} \mathrm{km}$

프 $>1.00 \mathrm{e}+01 \mathrm{uCi} / \mathrm{m} 2$

$0.58 \mathrm{sq} \mathrm{km}$

$\square>1.00 \mathrm{e}+00 \mathrm{uCi} / \mathrm{m} 2$

$5.76 \mathrm{sq} \mathrm{km}$

$\square>1.00 \mathrm{e}-01 \mathrm{uCi} / \mathrm{m} 2$

$12.65 \mathrm{sq} \mathrm{km}$

$\square>1.00 \mathrm{e}-02 \mathrm{uCi} / \mathrm{m} 2$

$15.77 \mathrm{sq} \mathrm{km}$ 
Appendix B.2 Worst case deposition plot (per kg of plutonium) for nearest offsite location.

Hydrotest Facility PSAR

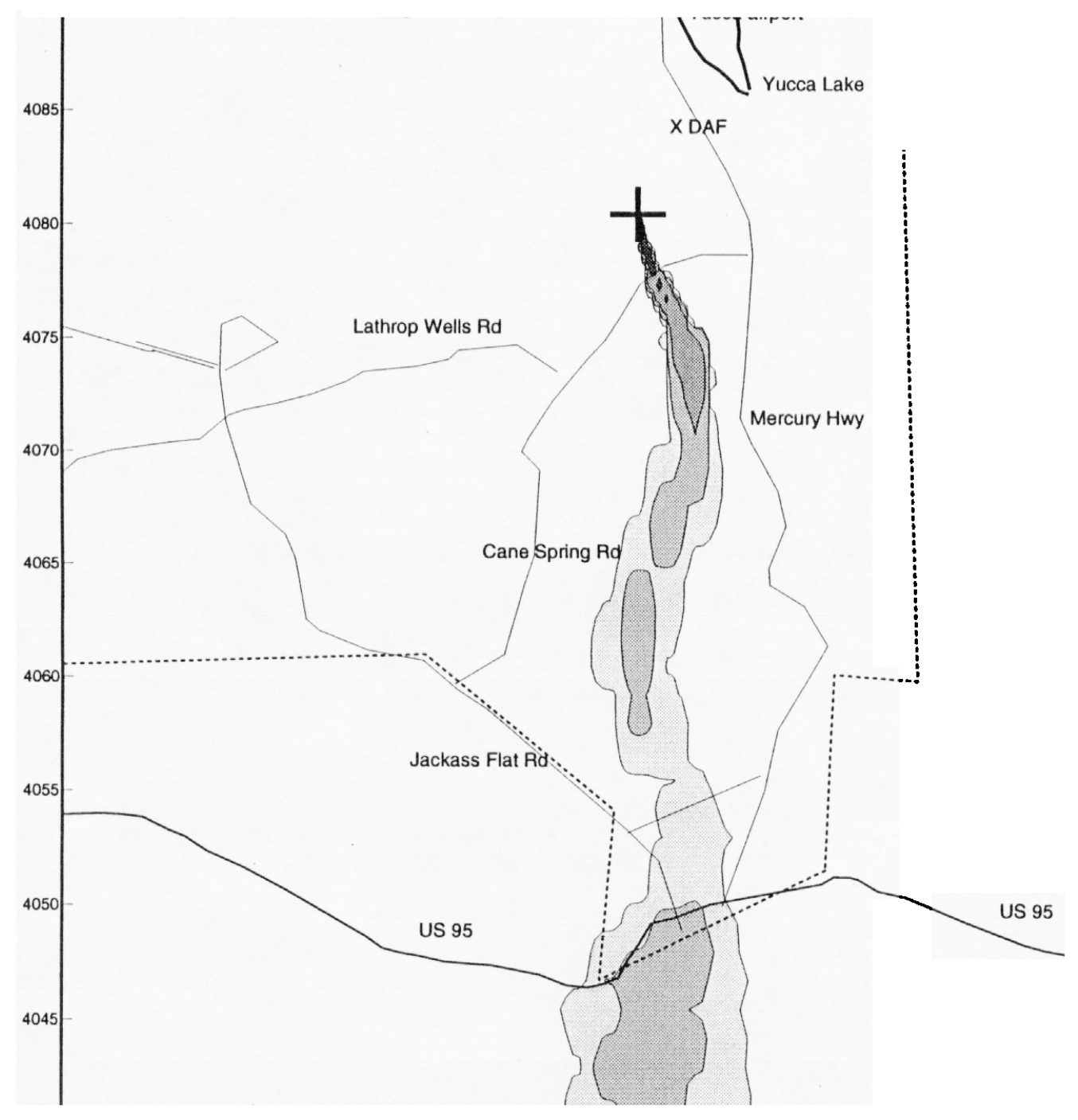

9SEP96 17:53:00 UTC

From Deposition at 0.0 meters

04MAR96 17:30:00 to 05MAR96 05:30:00 UTC

Weapon-grade $\mathrm{Pu}$

Source Location (longitude, latitude)

$116^{\circ} 03^{\prime} 47^{\prime \prime} \mathrm{W}, 36^{\circ} 52^{\prime} 05^{\prime \prime} \mathrm{N}$

Source Location ( $x, y$, projection)

$583.52 \mathrm{~km} \mathrm{E.} 4080.46 \mathrm{~km} \mathrm{~N}$. UTM

INITIAL PLOT - WEAPON ACCIDENT D

$50 \mathrm{lb} . \mathrm{HE}, \mathrm{E}$ stability,

(per kilogram of weapon-grade $\mathrm{Pu}$ )

\begin{tabular}{lr} 
(Level and Area Covered) & \\
$>$ & $1.00 \mathrm{e}+02 \mathrm{uCi} / \mathrm{m} 2$ \\
$>1.00 \mathrm{e}+01 \mathrm{uCi} / \mathrm{m} 2$ & $0.09 \mathrm{sq} \mathrm{km}$ \\
\hline$>1.00 \mathrm{e}+00 \mathrm{uCi} / \mathrm{m} 2$ & $7.19 \mathrm{sq} \mathrm{km}$ \\
$\square>1.00 \mathrm{e}-01 \mathrm{uCi} / \mathrm{m} 2$ & $62.38 \mathrm{sq} \mathrm{km}$ \\
$\square>1.00 \mathrm{e}-02 \mathrm{uCi} / \mathrm{m} 2$ & $147.51 \mathrm{sq} \mathrm{km}$
\end{tabular}


Appendix C.1 Worst case atmosphere beryllium concentration plot (per kg of Be) for nearest onsite location.

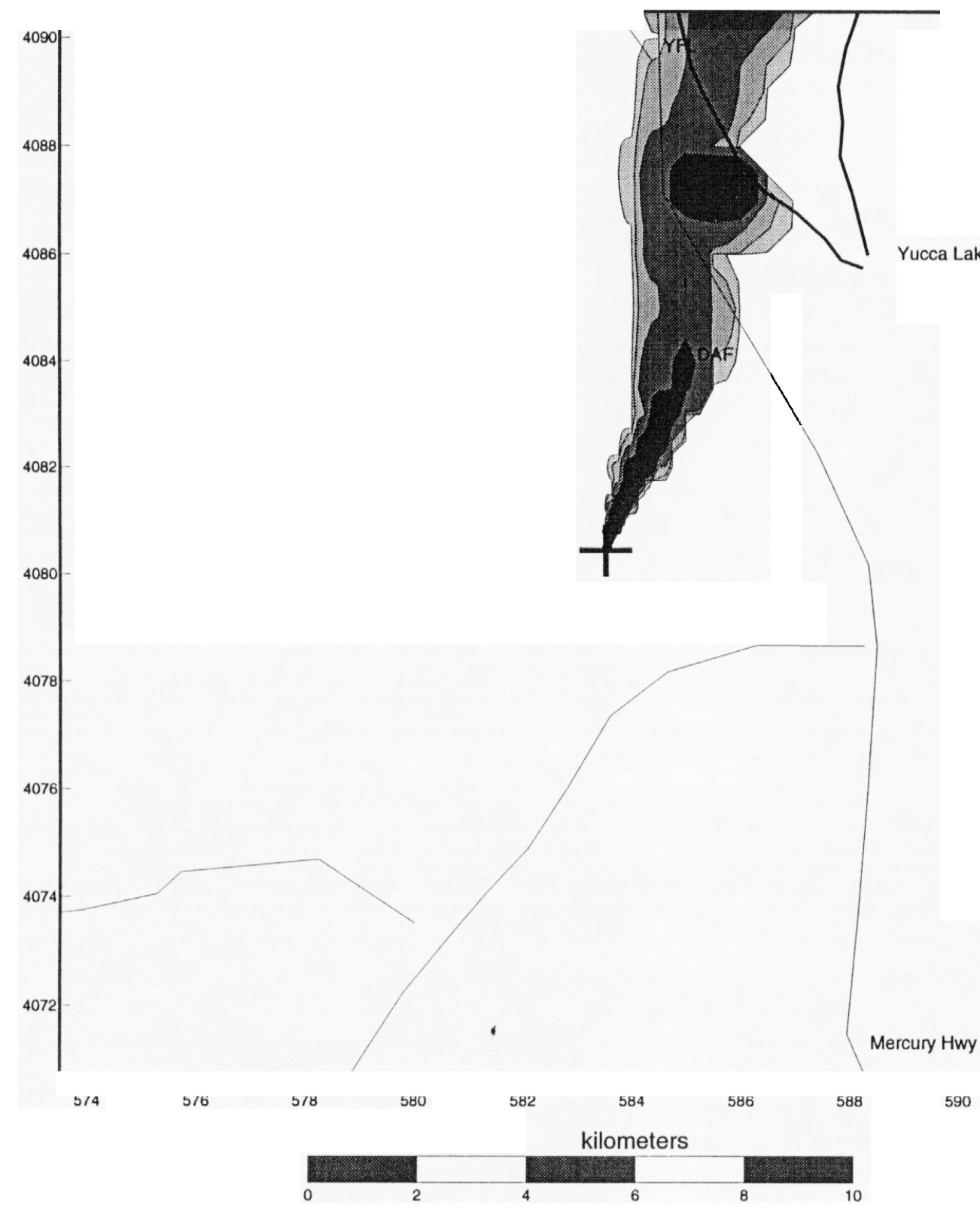

Advanced

\section{Facility PSAR}

\section{SEP96 16:28:00 UTC}

Contour Type

Max 5-min avg. air conc. at $1.5 \mathrm{~m}$

04MAR96 17:30:00 to 05MAR96 05:30:00 UTC

I'Bervillium

I116. $03^{\prime} 47^{\prime \prime}$ W. $36^{\circ} 52^{\prime} 05^{\prime \prime} \mathrm{N}$

I $58.352 \mathrm{~km} \mathrm{~F}$ AกRก $46 \mathrm{~km} \mathrm{~N}$ IITM

INITIAL PLOT . WEAPON ACCIDENT D

$50 \mathrm{lb}$. HE, F stability

(per kg. of aerosolized Beryllium)

tcute Public Exposure Levels:

Level and Area Covered)

드 $1.00 \mathrm{e}-03 \mathrm{mg} / \mathrm{m} 3$

$3.27 \mathrm{sq} \mathrm{km}$

글 $1.00 \mathrm{e}-04 \mathrm{mg} / \mathrm{m3}$

$11.96 \mathrm{sq} \mathrm{km}$

$\Longrightarrow 1.00 \mathrm{e}-05 \mathrm{mg} / \mathrm{m3}$

$16.46 \mathrm{sq} \mathrm{km}$ 
Appendix C.2 Worst case atmosphere beryllium concentration plot (per kg of Be) for nearest offsite location.

\section{Advanced Hydrotest Facility PSAR}

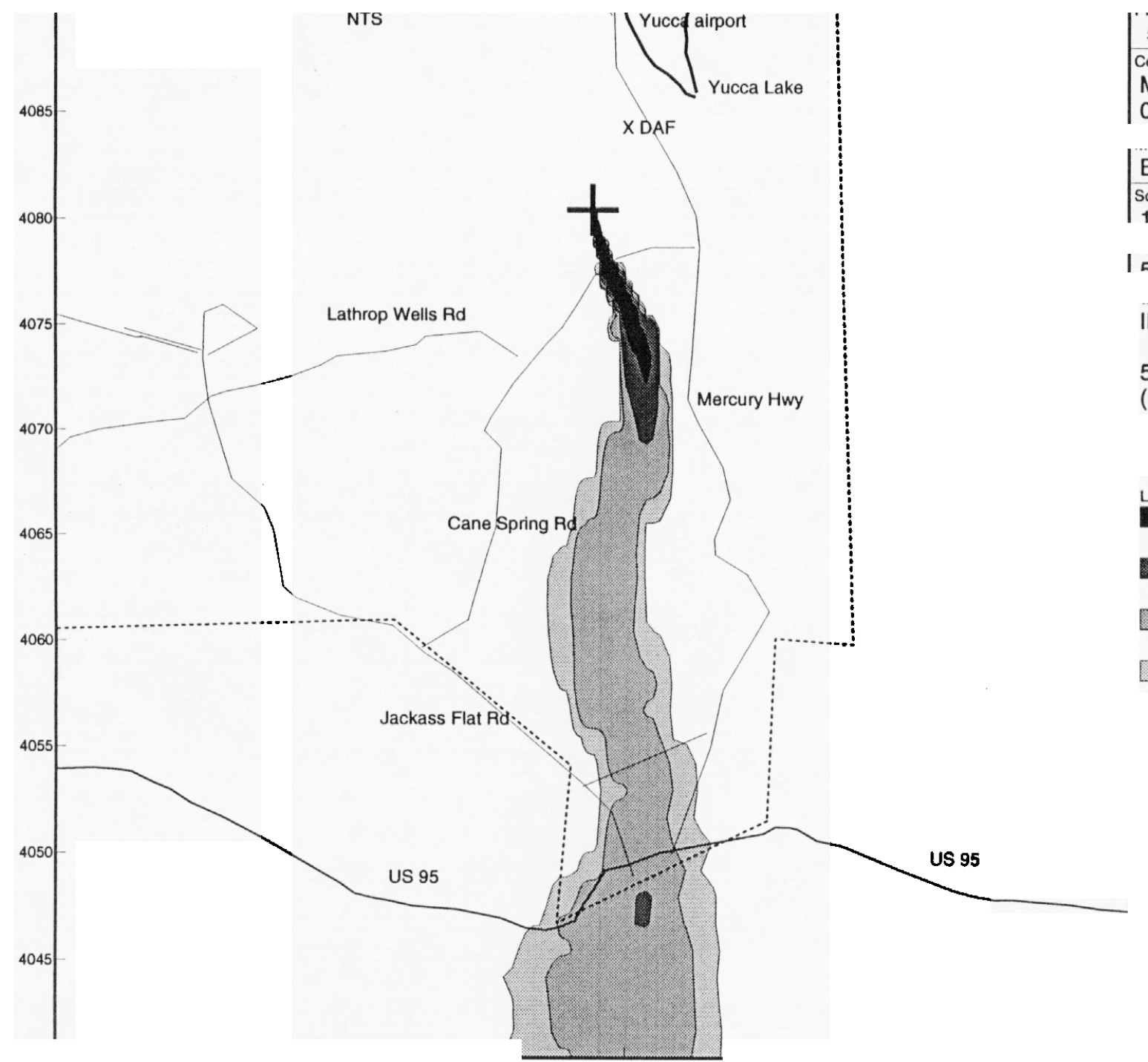

\section{SEP96 16:17:00 UTC}

Contour Type

Max 5-min avg. air conc. at $1.5 \mathrm{~m}$

04MAR96 17:30:00 to 05MAR96 05:30:00 UTC

\section{Beryllium}

Source Location (longitude, latitude)

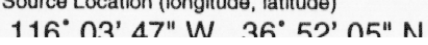

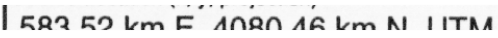

INITIAL PLOT - WEAPON ACCIDENT D

$50 \mathrm{lb} . \mathrm{HE}, \mathrm{E}$ stability

(per kg. of aerosolized Beryllium)

\section{Level and Area Covered}

$>1.00 \mathrm{e}-03 \mathrm{mg} / \mathrm{m} 3$

$4.68 \mathrm{sq} \mathrm{km}$

$>1.00 \mathrm{e}-04 \mathrm{mg} / \mathrm{m} 3$

$13.04 \mathrm{sq} \mathrm{km}$

I $1.00 \mathrm{e}-05 \mathrm{mg} / \mathrm{m} 3$

$128.95 \mathrm{sq} \mathrm{km}$

प $1.00 \mathrm{e}-06 \mathrm{mg} / \mathrm{m3}$

191.94 sq km 
Appendix D.1 Worst case atmospheric HF concentration plot for nearest onsite location.

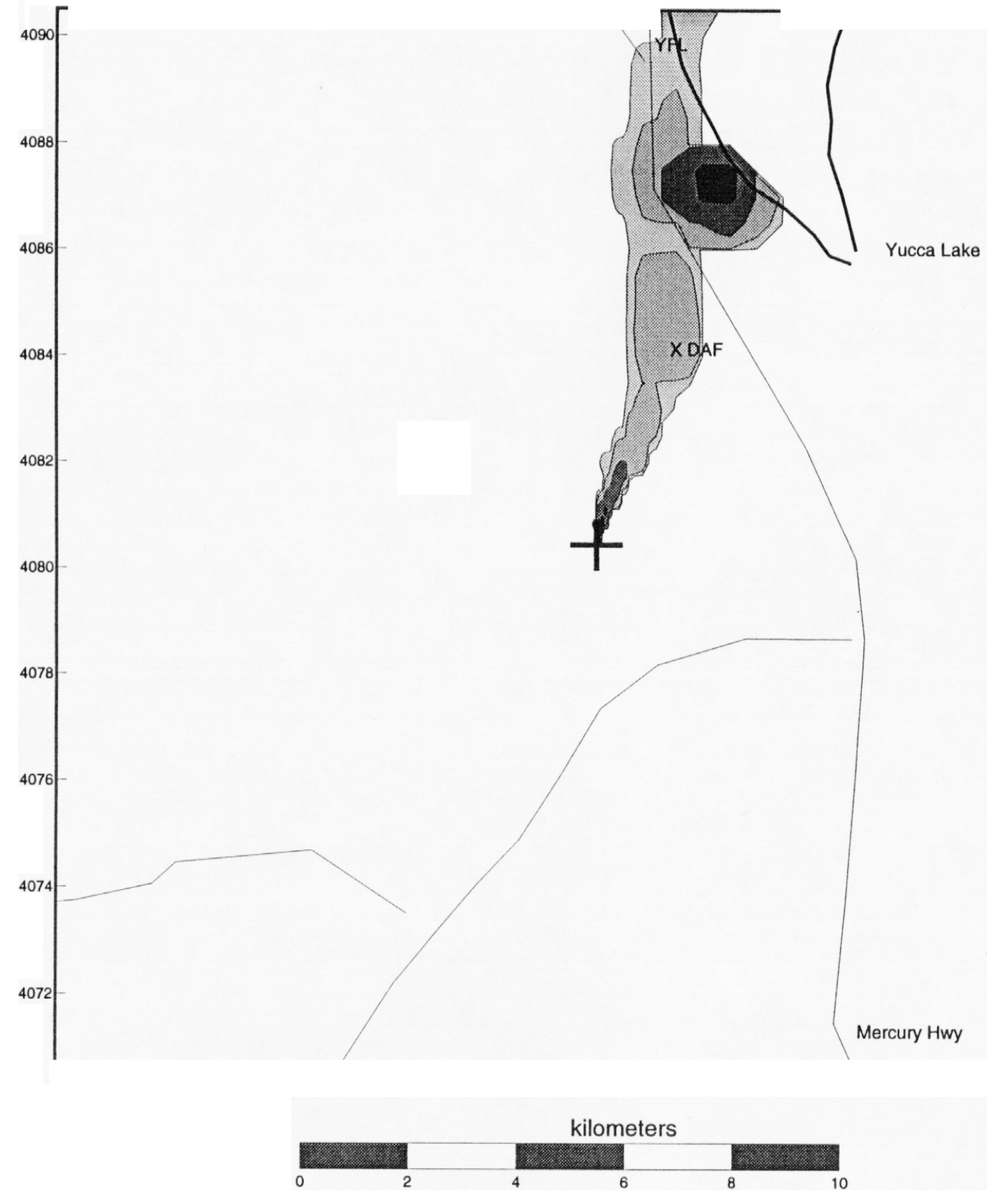


Appendix D.2 Worst case atmospheric HF concentration plot for nearest location.

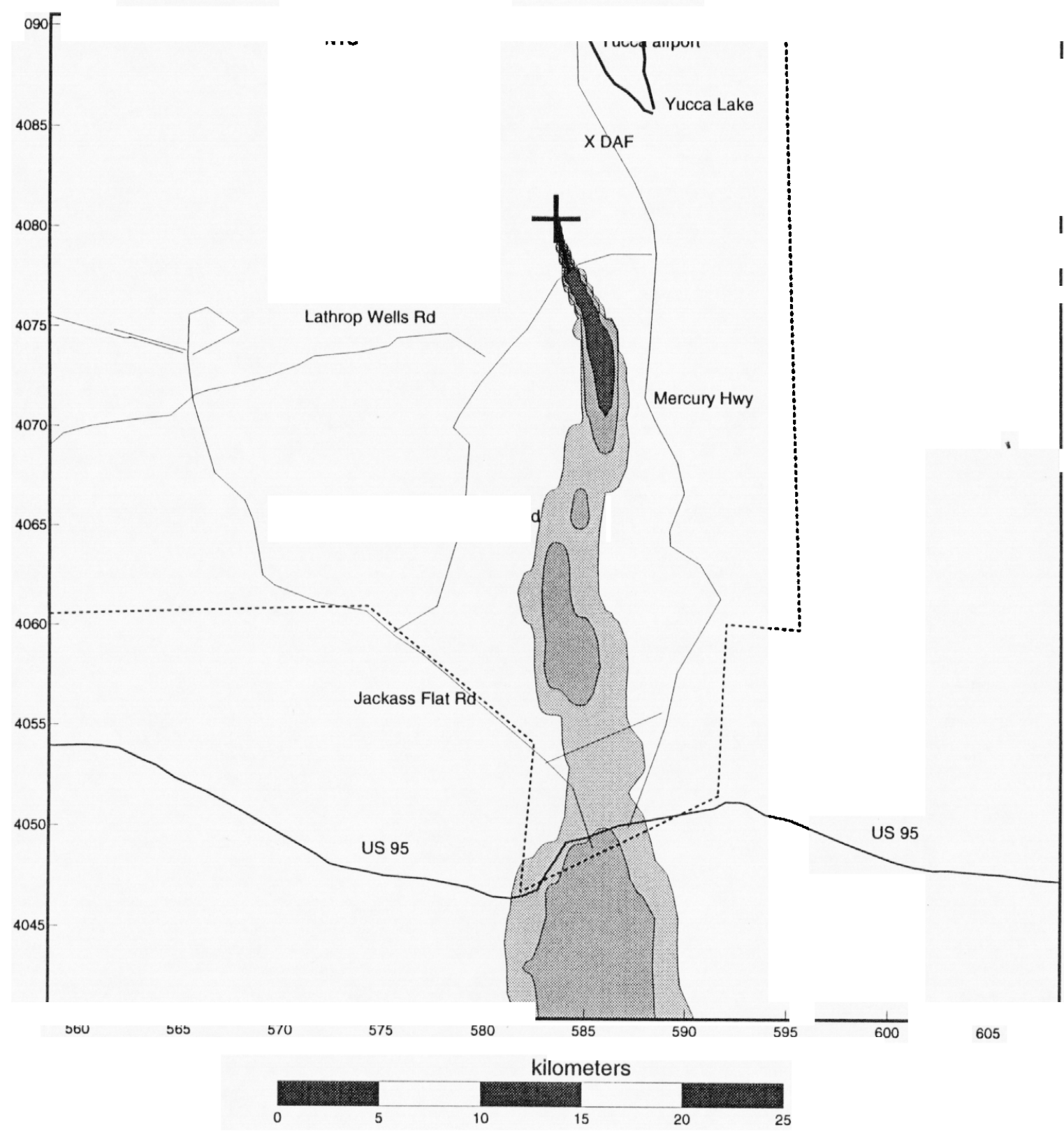

Advanced Hydrotest Facility PSAR

I 15APROG 16.26.กก I ITR.

Max 5-min avg. air conc. at $1.5 \mathrm{~m}$

04MAR96 17:30:00 to 05MAR96 05:30:00 UTC

HYDROGEN FI IJORINF

$116^{\circ} n 3^{\prime} 47^{\prime \prime} W \quad 36^{\circ} 52^{\prime} n 5^{\prime \prime} N$

I 583.52 km E. 4080.46 km N. UTM

INITIAL PLOT - WEAPON ACCIDENT D

Dense gas effects not included

$100 \mathrm{lb}$. HE, E stability

Total release $=1818$ grams of $\mathrm{HF}$

들 $1.00 \mathrm{e}-02 \mathrm{ppm}$

$0.39 \mathrm{sq} \mathrm{km}$

$>1.00 \mathrm{e}-03 \mathrm{ppm}$

$7.46 \mathrm{sq} \mathrm{km}$

$>1.00 \mathrm{e}-04 \mathrm{ppm}$

$75.08 \mathrm{sq} \mathrm{km}$

$\square>1.00 \mathrm{e}-05 \mathrm{ppm}$

$164.62 \mathrm{sq} \mathrm{km}$ 


\section{Appendix E. Permissible limits.}

ARAC uses the following action guides for whole-body dose and deposition when supporting the Department of Defense (see NARP, 1990)

Whole body dose:

5 Rem: Respiratory protection is required, recommend sheltering, consider evacuation.

0.5 Rem: Consider sheltering

Deposition:

$60 \mu \mathrm{Ci} / \mathrm{m}^{2}$ : Supervised area: issue sheltering instructions and recommend controlled evacuation 2-14 days.

$6 \mu \mathrm{Ci} / \mathrm{m}^{2}$ : Access on need-only basis; possible controlled evacuation required.

ARAC uses Emergency Response Planning Guidelines (ERPGs) for beryllium and HF: beryllium

The maximum airborne concentration
below which it is. believed that nearly all
individuals could be exposed for up to
one hour without experiencing or
developing life-threatening health effects.

ERPG-2 The maximum airborne concentration

$\underline{\left(\mathrm{mg} / \mathrm{m}^{3}\right)}$

0.1

HF (ppm)

50

.025

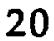

below which it is believed that nearly all individuals could be exposed for up to one hour without experiencing or developing irreversible or other serious health effect or symptoms which could impair an individual's ability to take protective action.

ERPG-1 The maximum airborne concentration below which it is believed that nearly all individuals could be exposed up to one hour without experiencing other than mild, transient adverse health effects or without perceiving a clearly defined objectionable odor. 


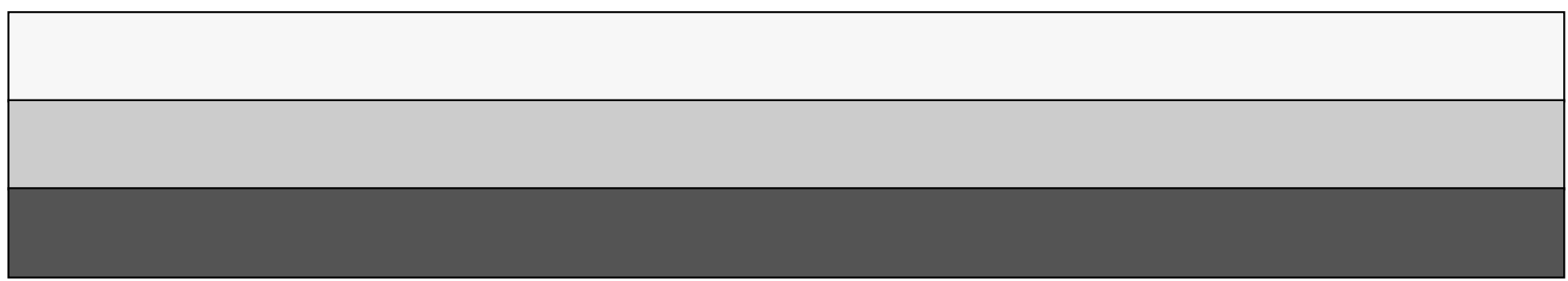

